\title{
Investigating the Impact of Instagram on Women Entrepreneurs' Empowerment
}

\author{
Ambar Sari Dewi* \\ Department of Sociology \\ Faculty of Social Sciences and Humanities \\ UIN Sunan Kalijaga Yogyakarta \\ ambarsaridewi@gmail.com
}

\begin{abstract}
The advent of social media has created new ways to interact, participate, cooperate, and collaborate with various parties in daily life, including business. Such features are beneficial for SMEs with limited resources and capabilities, particularly women entrepreneurs. Literature have shown that using social media can help women worldwide to empower themselves in political, social, cultural and economic sectors. Social media characteristics allow users to share information, participate, interact and modify contents to help women empowerment. Considering the large number of women entrepreneurs in Indonesia, it is important to examine how women in Indonesia use social media as an empowerment tool for them. Using qualitative content analysis, this study categorizes the content of text and visual data on social media, particularly Instagram owned and operated by womenentrepreneurs. Data were collected from two Instagram accounts owned by two women-entrepreneurs in Yogyakarta, Indonesia. An iterative analysis was then conducted by comparing data with theoretical concepts used in this research. This research found that in both cases social media elements were utilised effectively. Furthermore, the decision to use Instagram and Facebook rather than other social media platforms was based on their experience in using these platforms. Social media, particularly Instagram allows also both cases to collaborate with other women entrepreneurs or other communities. This study concluded that women empowerment is shown on how the women entrepreneurs studied use social media. Social media contents on these two accounts are one of the ways for these women actualize themselves.
\end{abstract}

Keywords-Women empowerment, qualitative content analysis, social media, Instagram

\section{INTRODUCTION}

The number of women entrepreneur (henceforth womenpreneur) in Indonesia has increased from 12.7 million to 14.3 million in 2015 and 2017 respectively. Women-preneur mostly focus their business in feminine products such as fashion, beauty, parenting, and craft. Duffy and Hund [1] noted that the contribution of women in entrepreneurship, especially in fashion industry, "interrelated tropes the destiny of passionate work, staging the glam life, and carefully curated social sharing" (p.2). Moreover, in developing countries like Indonesia, the increasing number of women-preneur also indicate the rise of women empowerment [2]; [3].

Women empowerment is defined as the process and changes of women's ability to make choices and control resources in an environment where choices were previously denied. Initiated in the 1970s, women empowerment has become a buzzed since then. The importance to empower women also increases as shown on the number of initiatives and research of the topic.

On the other hand, the advent of social media has created new ways to interact, participate, cooperate, and collaborate with various parties in daily life, including business. Such features are beneficial for SMEs with limited resources and capabilities, particularly women entrepreneurs. Nevertheless, there have been limited study on how small-medium enterprises (SMEs), particularly owned by women, on how they use social media to empower themselves. Consequently, there are some gaps in the body of knowledge because SMEs, particularly in developing countries such as Indonesia, hold important role to the development of this nation as shown in their contribution to the country's employment and Gross Domestic Product (GDP). In 2013, there were 57.8 million SMEs in Indonesia, accounting for more than $90 \%$ of all companies. Indonesian SMEs were the largest source of employment, covering 114 million people or $97 \%$ of the country's total workforce. SMEs also contribute $60 \%$ of Indonesia's GDP in 2014.Based on background above, this research focus on how Indonesian women-preneurs use social media to support empowerment in economic.

\section{LITERATURE REVIEW}

\section{A. Women empowerment}

Although concern about empowering women has been discussed by various scholars, the concept of women empowerment was initiated by third-world feminists and women organizations in the 1970s [4]. While the concept is evolving, its definitions still vary. For example, Keller and Mbewe [5] define women empowerment as a process of women's ability to increase self-reliance, assert their right to make choices and control resources. These abilities will eventually assist women to challenge and reduce subordination. Furthermore, Bennett (in [6] p. 4) describes empowerment as the improvement of assets and capabilities of various individuals and groups to participate, affect and ask responsibility from the institutions which affect them.

Another definitions of women empowerment was proposed by Kabeer [7] highlighting the importance of the process of women's ability to make strategic life choice in an environment where choices were previously denied. Kabeer's definition of women empowerment contains two important elements, which differentiate it from other closely related concepts: 1. Process or change, which indicate 
empowerment as an improved condition from disempower to empower; and 2. Human agency and choice, which refer to the freedom and willingness to exert one's choice without severe consequences [6] p. 4.

Based on discussion above and to achieve the purpose of this research, definition of women empowerment used in this research is the process and changes of women's ability to make choices and control resources in an environment where choices were previously denied.

\section{B. Social media and women-preneur empowerment}

Scholars have defined social media from various views. For example, Kaplan and Haenlein [8] pointed out the main features of social media, Web 2.0 and user-generated content; distinguish social media from other internet applications. Thus, social media refers to "a group of internet-based applications that build on the ideological and technological foundations of Web 2.0, that allows the creation and exchange of User Generated Content"[9]. In this research, the term social media will refer to those interactive web platforms that enable users to share, create, and exchange information and knowledge in the form of text, video, audio, and pictures.

Sayal [10] proposes four elements of social media, namely content, context, connection and communication. Content/information is the basis of social media as it works on the theme of information sharing. Users use social media to have access to certain kinds of information, such as pictures, videos, blogs, etc. Furthermore, context refers to the characteristics of each social media platform. Since each platform has its own language, some contents in a platform may not fit in others. Connection refers to the social element of social media which enables large number of people to connect with each other or building a community. Communication is defined as true purpose of social media, that is, to communicate with people. As such, information based in context has to be communicated to a set of people effectively and fast.

The advent of social media has created new ways to interact, participate, cooperate, and collaborate with various parties in daily life, including business. Social media offers an internet-based interactive application that allows users to share information, participate, interact and modify contents [11, 8, 12, and 9]. Such features are beneficial for SMEs with limited resources and capabilities.

With regards to women empowerment, it is argued that social media, with its networking capabilities, is an important route to empowerment due to the access to resources and opportunities. Studies on empowering women with social media show that the tool can be utilised for communication and self-expression, civic participation, social change, women's rights and economic empowerment [13]. For example, social media sites such as Facebook, Twitter, and YouTube played an important role in women engagement in the Arab Spring and in their political empowerment [14].

In economic sectors, Ajjan et al [15] proposed a conceptual model based on the concepts of social capital and self-efficacy to examine the use of social media in empowering women entrepreneurs in emerging country. The model was then tested by Beninger et al [3] who found that social media has an overall positive impact on the lives of women entrepreneurs in Egypt, both personally and professionally. Furthermore, Alam et al [16] investigate the key factors affecting success of women entrepreneurs in Southern region in Malaysia. The results suggest some factors affecting the success of women entrepreneur, such as, family support, social ties and internal motivation. In Indonesian economic context, Sudarmanti [17] studies the relationship between the uses of social media (Facebook/Instagram) as marketing online media with the happiness of women-preneur. Using survey as her research method, the research found that the relationship between the usage intensity of social media provides a feeling of happiness for businesswomen on certain level.

Based on literature reviewed above, it is clear that using social media can help women worldwide to empower themselves, because there are many potentials of using social media platforms as a tool to do so. Hence, it is important to examine how women in Indonesia use social media as an empowerment tool for them.

\section{METHODOLOGY}

Using qualitative content analysis, this study categorizes the content of text and visual data on social media, particularly Instagram owned and operated by womenpreneurs. Qualitative content analysis enables researchers to understand the text by grouping words that have the same meaning into categories, which will eventually build a conceptual model or system [21]. Thus, analysis of qualitative content is more about developing data that can be interpreted to find theoretical significance.

Data were collected from two Instagram accounts owned by two women-entrepreneurs in Yogyakarta, Indonesia ${ }^{1}$. Moreover, in-depth interviews were conducted with the owners and co-founders. Texts and visuals from both Instagram accounts were coded and categorized into four Cs as suggested by Sayal (2019), namely content, context, communication, and connection. An iterative analysis was then conducted by comparing data with theoretical concepts used in this research.

\section{THE IMPACT OF INSTAGRAM IN EMPOWRING WOMEN ENTREPRENEUR}

\section{A. The case studies}

Founded in the 2000's, both firms produce women clothes using traditional woven such as batik and lurik. L, the owner Firm A, is 45-years-old and started business after she uploaded her clothing range to Facebook. Together with her husband, L operates Firm A with more than 15 tailors and five staff responsible for in-store sales, quality control, and distribution. In 2013, L created Firm A's Instagram account and continued to use these social media until Facebook suspended her account in 2015. The suspension

\footnotetext{
1 The owner's names and the firm's Instagram accounts are hidden
} accoding to research's ethic and consent. 
affected L's business since she could not access her uploaded pictures. She then created a Facebook fan page but remained upset from not being able to save her pictures.

Firm B was founded by IMD (female, 35 years-old) in Jogjakarta as her final assignment when she was a student at the School of Economics and Management of a private university in Jogjakarta. After graduated, IMD continued Firm B with her husband, TA. Firm B grows significantly since the couple used social media in 2009. From a capital of IDR 3 million in 2002, it earned IDR 300 million profit per month, producing approximately 1,000 pieces a month in 2016. Its business has also expanded, from less than ten staff (including batik makers and managers) in 2002, to more than 60 people in 2016.

Both cases have more than one social media accounts, however, this study will only examine their Instagram accounts as it provide text and visual data. Table. 1 depicts both firms' Instagram profile.

TABLE I. INSTAGRAM PROFILE OF FIRM A AND FIRM B

\begin{tabular}{|l|c|c|c|c|}
\hline \multirow{2}{*}{ Cases } & \multicolumn{4}{|c|}{$\begin{array}{c}\text { Instagram profile } \\
\text { (as per November 2016) }\end{array}$} \\
\cline { 2 - 5 } & $\begin{array}{c}\text { Number of } \\
\text { followers }\end{array}$ & $\begin{array}{c}\text { Number of } \\
\text { posts }\end{array}$ & $\begin{array}{c}\text { Number of } \\
\text { comments }\end{array}$ & $\begin{array}{c}\text { Number of } \\
\text { likes }\end{array}$ \\
\hline Firm A & 17,723 & 3,000 & 5,809 & 82,000 \\
\hline Firm B & 39,638 & 2,159 & 2,771 & 99,653 \\
\hline
\end{tabular}

As can be seen in the table above, it is clear that both cases have used Instagram actively. Both accounts also have good engagement as shown in the number of comments and likes. The next section will explain findings related to the effect of Instagram on women empowerment.

\section{B. The effect of Instagram on women-preneur's empowerment}

This research found that in both cases social media elements were utilised effectively. Based on Sayal's (2019) elements of social media, this study found that content on both Instagram accounts were text and photos/pictures (see Table II). Texts and pictures are Instagram main features which differentiate it with other social media platform in its beginning development. Further, the Instagram added video in its platform in 2013, which became popular since then. Nevertheless, in Firm A and Firm B's cases, videos were rarely posted.

TABLE II. NUMBER OF POSTS AND CONTENTS ON INSTAGRAM

\begin{tabular}{|c|c|c|c|c|c|c|}
\hline \multirow{2}{*}{ Cases } & \multicolumn{4}{|c|}{ Type of posts } & \multicolumn{2}{c|}{ Types of content } \\
\cline { 2 - 7 } & texts & photos & videos & links & $\begin{array}{c}\text { Product } \\
\text { information }\end{array}$ & Others \\
\hline Firm A & 2929 & 2965 & 0 & 217 & 22935 & 30 \\
\hline Firm B & 2159 & 2159 & 4 & 533 & 1709 & 450 \\
\hline
\end{tabular}

Sayal (2019) argues that each social media platform has its own language, thus, content should be created to fit with such context. Among other social media platforms, Instagram users rely on pictures they uploaded and strengthen with captions. In this research, both L and IMD mostly posted products information on their social media accounts. The two Instagram accounts visually applied bright colour that clearly showed their products.

Furthermore, Firm B utilised its Instagram account to deliver its brand knowledge by using explicit promotion messages better than Firm A. Additionally, Firm B's Instagram feed was all about promotion messages of their products, while Firm A mixed the content of its Instagram accounts with the owner's personal daily activities. As such, Firm A was more contextual than Firm B. As L of Firm A said:

"[...] I create an Instagram account to promote clothes worn by my customers. So, I use Instagram as a hub to whoever has bought my products, [and asked them to] send their photos or tag my Instagram account. [Then] I'll repost them. It turns out that my customers love it."

With regards to communication, both accounts communicated with their follower using clear messages. Information about their products were displayed clearly. In terms of connection, both cases have high level of interactivity as shown in the high level of engagement depicted in Table I. such engagement allows Firm A and Firm B to connect with their followers, not only to market their products, but also to build community. As Firm B said:

"I ask my employees to open their minds. I send some of them to join a writing community, or other positive communities. I also encourage them to create their own social media account, beside our official account and join forums that are positive for personal development"

\section{DISCUSSION}

Previous literatures have discussed women empowerment as the process and changes of women to make choices and control resources. In this research, ability to make choices was shown on the social media platform used in their business. The decision to use Instagram and Facebook rather than other social media platforms were based on their experience in using these platforms. As $L$ of Firm A said:

"I think if I didn't start [my business] on Facebook, I wouldn't have as many customers as now, both on my online and offline stores. Firm A's [offline] store was established after everyone recognised its brand on Facebook."

Furthermore, social media, particularly Instagram allows both cases to collaborate with other women-preneurs or other communities. For example, in 2015, IMD of Firm B and some female entrepreneurs established the Jogja Muslimah-Preneur (JMP) community (Women Muslim Entrepreneurs of Jogjakarta). The aim of this community is to improve the capabilities of Muslim women from various backgrounds by providing activities, such as regular meetings, workshops, and religious study. This community is important because it provides opportunities to connect with other SMEs, extend networks of potential partners, and improve capacity building. As the chair of this community, IMD leveraged Firm B's social media accounts as an information channel for the JMP's communication. 
Based on the findings above, this study concluded that women empowerment is shown on how the womenpreneurs studied use social media. Social media contents on these two accounts are one of the ways for these women actualize themselves, for example, through the use of bright colours and motivational captions. In addition, life-work balance as another form of women's empowerment is shown in several photos of their daily activities as women.

\section{CONCLUSION}

This research has argued that social media, particularly Instagram, is a valuable resource for empowering womenpreneurs. Instagram opens many possibilities and allows women to make choices as well as control them.

\section{REFERENCES}

11] Duffy, B. E., \& Hund, E. (2015). "Having it all" on social media: Entrepreneurial femininity and self-branding among fashion bloggers. Social Media + Society, 1(2), 2056305115604337.

[2] Tambunan, T. (2009). Women entrepreneurship in Asian developing countries: Their development and main constraints. Journal of Development and Agricultural Economics, 1(2), 27-40.

[3] Beninger, S., Aijan, H., Mostafa, R. B., \& Crittenden, V. L. (2016). A road to empowerment: social media use by women entrepreneurs in Egypt. International Journal of Entrepreneurship and Small Business, 27(2-3), 308-332.

[4] Mosedale, S. (2005). Assessing women's empowerment: towards a conceptual framework. Journal of international development, 17(2), 243-257.

[5] Keller, B. and Mbewe, D.C. (1991) 'Policy and planning for the empowerment of Zambia's women farmers', Canadian Journal of Development Studies/Revue, Vol. 12, No. 1, pp.75-88.

[6] Malhotra, A., Schuler, S., \& Boender, C. (2002). Measuring women's empowerment as a variable in international development. International Center for Research on Women and the Gender/Development Group of the World Bank. Washington D.C. MarkPlus Insight. (2011). Pengguna Internet di Indonesia. MarkPlus Ins

[7] Kabeer, N. (1999). Resources, agency, achievements: Reflections on the measurement of women's empowerment. Development and change, 30(3), 435-464

[8] Kaplan, A.M. and Haenlein, M. (2010) 'Users of the world, unite! The challenges and opportunities of social media', Business Horizons, Vol. 53, No. 1, pp.59-68
[9] Safko, L., \& Brake, D. K. (2009). The social media bible: Tactics, tools, and strategies for business success. Hoboken: Wiley John \& Sons.

[10] Deepa Sayal, "Digipedia: the basic guide to digital marketing and transformation", 2019, Notion Press, India.

[11] Boyd, D. M., \& Ellison, N. B. (2007). Social network sites: Definition, history, and scholarship. Journal of computer-mediated Communication, 13(1), 210-230.

[12] Kietzmann, J. H., Hermkens, K., McCarthy, I. P., \& Silvestre, B. S. (2011). Social media? Get serious! Understanding the functional building blocks of social media. Business horizons, 54(3), 241-251.

[13] Dubai School Of Government, 2011, "Role of Social Media in Arab Women's Empowerment", Arab Social Media Report, November Vol. 1, No. 3, viewed 25 April 2014, http://www.arabsocialmediareport.com/UserManagement/PDF/ASM R\%20Report\%203.pdf

[14] Newsom, V. A., \& Lengel, L. (2012). Arab Women, Social Media, and the Arab Spring: Applying the framework of digital reflexivity to analyze gender and online activism. Journal of International Women's Studies, 13(5), 31-45.

[15] Ajjan, H., Beninger, S., Mostafa, R. and Crittenden, V. (2014) 'Empowering female entrepreneurs in emerging markets: a conceptual model', Organizations and Markets in Emerging Economies, Vol. 5, No. 1, pp.16-30.

[16] Alam, S. S., Jani, M. F. M., \& Omar, N. A. (2011). An empirical study of success factors of women entrepreneurs in southern region in Malaysia. International Journal of economics and Finance, 3(2), 166175.

[17] Sudarmanti, Rini. (2020). The Relationship between Intensity Usage of Social Media with Women's Small Online Business Happiness. 10.4108/eai.5-11-2019.2292516.

[18] Dubai School Of Government, 2011, "Role of Social Media in Arab Women's Empowerment", Arab Social Media Report, November Vol. 1, No. 3, viewed 25 April 2014, http://www.arabsocialmediareport.com/UserManagement/PDF/ASM R\%20Report\%203.pdf

[19] Sudarmanti, Rini. (2020). The Relationship between Intensity Usage of Social Media with Women's Small Online Business Happiness. 10.4108/eai.5-11-2019.2292516.

[20] Boyd, D. M., \& Ellison, N. B. (2007). Social network sites: Definition, history, and scholarship. Journal of computer-mediated Communication, 13(1), 210-230.

[21] Elo, S., \& Kyngäs, H. (2008). The qualitative content analysis process. Journal of advanced nursing, 62(1), 107-115. 